\title{
Instituições, normas e monacato em Leão e Castela (séc. XIII)
}

Maria Filomena Coelho*

Resumo: Este artigo propõe-se a explicar o problema da clausura na perspectiva da cultura política em que se vivenciaram as regras monásticas, com especial destaque para o monacato feminino cisterciense de Leão e Castela, no século XIII. Pretende-se apontar aspectos que ajudem a compreender de que forma se entrelaça o processo de institucionalização do ramo feminino da Ordem de Cister ao da fundação e/ou de reconhecimento oficial de casas monásticas, no qual a clausura era frequentemente um argumento normativo de peso. As tensões e os conflitos registrados nos documentos ligados ao cumprimento da clausura, ao reconhecimento jurídico dos mosteiros ou aos vínculos jurisdicionais, devem ser interpretados no contexto político de cada reino e de cada região, sem esquecer as redes políticas e sociais em que estavam envolvidos aqueles atores.

Palavras-chave: Monacato Medieval. Clausura. Ordem de Cister. Cister Castelhano-Leonês.

\section{Introdução}

A clausura é a instituição por excelência do monacato. Viver enclausurado para afastar-se do mundo e dos perigos que ameaçam a virtude é o objetivo primordial que dava identidade a monges e monjas na Idade Média, e essa especificidade deveria ser ciosamente guardada e perseguida por aqueles encarregados de dirigir as comunidades monásticas, a ponto de se registrar por escrito as normas que deveriam reger a clausura.

\footnotetext{
* Professora Adjunta de História Medieval no Departamento de História da UnB. Coordenadora do Programa de Estudos Medievais (PEM-UnB). E-mail: filo-coelho@hotmail.com
}

Anos 90, Porto Alegre, v. 20, n. 38, p. 127-149, dez. 2013 
Entretanto, a maneira como esses homens e essas mulheres de religião relacionavam-se com as regras, como as viviam e experimentavam, parece assemelhar-se à forma como a sociedade laica se relacionava com as leis. Entendia-se que a lei era um instrumento importante pelo qual se orientava a vida, mas que convivia e concorria com outros elementos igualmente importantes que obrigam e vinculam os homens e as mulheres em sociedade.

Embora a análise da historiografia sobre o tema não seja o objetivo central deste artigo, é preciso dizer que com muita frequência a clausura aparece com grande destaque nas obras de referência. Por ser entendida pelos historiadores das instituições do monacato como pedra fundamental da vida religiosa feminina medieval, a lógica da análise sobre a clausura recai muitas vezes na dicotomia cumprimento-descumprimento e, principalmente, na capacidade-incapacidade da autoridade suprema da instituição em submeter os faltosos.

Assim, com este artigo, pretende-se propor uma reflexão que encare o problema da clausura na perspectiva da cultura política, ou seja, dos valores em que se assentam e pelos quais se justifica o poder de exigir a observância da clausura, bem como o de permitir as exceções. Sobre essa questão fundamental, apoiou-se grande parte do discurso que deu existência institucional ao monacato feminino cisterciense de Leão e Castela, no século XIII. A depender dos jogos políticos, ora a clausura aparece como um valor inegociável, por ser entendido como essência da identidade "mosteiro feminino", ora sequer é mencionada ou cumprida, sem que se registrem censuras. A leitura atenta da documentação permite concluir que "cada caso é um caso", pois a obrigatoriedade da aplicação da regra da clausura estará sujeita às circunstâncias que envolvem os atores relacionados ao mosteiro em questão, eclesiásticos e laicos. Como toda regra, também a monástica prevê exceções e, no que se refere à clausura, a própria autoridade jurídica se encarrega de distribuir privilégios nesse sentido, que muitas vezes são o mero reconhecimento de situações de fato. Neste sentido, a clausura aparece como um valor institucional reforçado e redimensionado pelas exigências da política. Mas a documentação também permite acompanhar a trajetória de mosteiros femininos que na mesma região e época tampouco observavam a clausura nos moldes estipulados pela 
norma, sem sofrerem qualquer tipo de advertência ou sanção. Estes casos, obviamente, merecem igual atenção por parte do historiador.

Ao longo das próximas páginas, portanto, pretende-se percorrer o caminho da 'institucionalização' do monacato feminino cisterciense em Leão e Castela, por meio de rastros documentais. A proposta concreta, cujo foco é a clausura, faz parte de uma preocupação maior ligada à necessidade de compreender o conceito de instituição para a Idade Média. Este conceito, fortemente marcado pela definição que lhe deu a modernidade, tem sido objeto de debate entre historiadores que se dedicam a estudar os períodos pré-modernos, por se entender que ele acaba por homogeneizar as instituições de forma anacrônica. O conceito precisa ser historicizado. O melhor caminho, ou seja, o melhor método, é tentar descobrir as lógicas que foram dando forma às instituições, ou como se institucionalizaram as instituições.

\section{A institucionalização da clausura feminina castelhano-leonesa}

A clausura feminina e o monacato castelhano-leonês inserem-se na tradição cristã, que vem do oriente e da Antiguidade.

A regra oriental de São Pacômio (séc. III-IV) é a principal referência com relação à clausura. Nessa regra, estabelece-se uma clausura rígida, que não permite contatos com o mundo exterior e um controle rígido sobre as saídas do mosteiro (VIDAL CELURA, 1986). Em termos arquitetônicos, os muros adquirem protagonismo, bem como a função do porteiro que, juntos, configuram o encelulamento. São Pacômio preocupou-se, ainda, em limitar ao máximo os contatos entre monges e monjas, permitindo apenas o suficiente para garantir o cumprimento das necessidades espirituais das religiosas. Outra regra famosa, também oriental, é a de São Basílio (séc. IV), que apresenta menor rigidez no que tange à clausura, alargando os contatos que as religiosas poderiam ter com a comunidade laica, sobretudo no âmbito das liturgias (SMITH, 2001). No século VI, São Cesário de Arles difunde sua regra, na qual exige a clausura estrita e perpétua, sobretudo para as monjas (VOGUÉ, 
1986, p. 183). É também desse século a regra de São Bento, que, no tocante à clausura, é bem menos rígida. Há ainda outras regras a destacar, como as de Santo Agostinho ${ }^{1}$, Aurélio de Arles e, sobretudo, as leis e orientações que vários concílios emitiram sobre o tema. De qualquer forma, nenhuma delas alcançou, no ocidente, o sucesso das regras de São Cesário de Arles e de São Bento (VIDAL CELURA, 1986, p. 123; VOGUÉ, 1986, p. 192-193). ${ }^{2}$ Portanto, de forma breve, importa destacar que a clausura tem grande importância para a história do monacato e que a diferença entre as propostas recai essencialmente sobre a sua rigidez. ${ }^{3}$

A partir do século IV, os concílios da Península Ibérica começam a legislar e a prever punições para os que desobedecessem aos preceitos de clausura, principalmente para evitar que as virgens consagradas se misturassem aos ascetas. São Leandro, preocupado com a clausura feminina, escreveu uma regra dedicada à sua irmã, na qual advertia sobre os perigos que supunham as amizades com mulheres casadas, homens e jovens, mesmo os virtuosos, e de conversas sem testemunhas. Os conselhos de São Leandro evidenciam sua preferência pela vida em comunidade, frente às experiências de reclusão solitária.

No quieras imitar a las virgenes que habitan en sus casas dentro de la ciudad. Visten con lujo para agradar a las gentes y las tareas domésticas les impiden el servicio de Dios (VIDAL CELURA, 1986, p. 301).

Santo Isidoro, sucessor de seu irmão, Leandro, na sé episcopal de Sevilha, escreveu, por volta de 618, uma regra inspirada nos princípios pacomianos e beneditinos. No que dizia respeito ao espaço, a inspiração vinha de Pacômio, com os muros altos, onde os monges deveriam permanecer conclavis, mas a organização da comunidade assentava-se sobre os princípios de São Bento. A Península receberá ainda a influência de outra regra monástica, a de São Frutuoso de Braga, que, com relação à clausura, tinha uma proposta bastante dura. Somente após o século $\mathrm{X}$, à raiz da difusão cluniacense, a regra de São Bento passa a dominar a experiência cenobítica ibérica. 
O Concílio de Coyanza $(1055)^{4}$ determina que todos os cenóbios femininos adotem a regra de São Bento, ao passo que os masculinos poderão também escolher a regra de Santo Isidoro.

Embora a regra de São Bento não dedique muita atenção à clausura, quando o faz é de forma rotunda: aeterna clausura damnamus. O tom dramático e radical, entretanto, será suavizado nos artigos seguintes quando regulam-se as relações sociais dos religiosos, as maneiras como dever-se-iam acolher os hóspedes, as saídas permitidas. Portanto, uma clausura eterna que contemplava muitas exceções. De qualquer forma, do ponto de vista dos princípios, a clausura parecia ser mais necessária para o monacato feminino do que para o masculino.

Quando, no final do século XII, os monges de Cister decidem reconhecer o ramo feminino da Ordem impõem a clausura como condição sine qua non para aceitar a incorporação dos mosteiros de monjas que já se declaravam cistercienses. Entre 1118 e 1132, Guy de Châtel-Censoir, sob a orientação dos famosos abades, Hugo de Pontigny, Bernardo de Claraval, Godofredo de Fontenay e Gaucher de Morimond, elabora alguns estatutos para as religiosas, nos quais se percebe especial preocupação com a clausura (BOUTON, 1986, p. 42). De fato, as primeiras monjas da Ordem não observavam o preceito da clausura. Ao contrário, sua vida cotidiana inspirava-se na rotina dos primitivos monges cistercienses, inclusive no tocante ao trabalho direto da terra (LECLERCQ, 1982, p. 47). Somente em 1184, transcorridos bastantes anos de sua fundação, a primeira abadia feminina cisterciense, Tart, receberá do papa Lúcio III a bula "Prudentibus Virginibus", com o intuito de regulamentar a clausura.

Em termos práticos, é preciso estabelecer a diferença entre a clausura passiva (que proíbe as entradas no mosteiro) e a clausura ativa (que proíbe as saídas) (VIDAL CELURA, 1986, p. 297). Os teóricos e legisladores citados até aqui se preocupavam principalmente com a clausura ativa, ou seja, com a circulação das monjas fora dos muros. Desde a época carolíngia, chegara-se à conclusão de que era praticamente impossível exigir que os cenóbios femininos cumprissem a clausura passiva. Por um lado, era preciso garantir a assistência religiosa por meio de capelães e, por outro, 
as necessidades materiais justificavam a circulação intramuros de criados, serventes, jornaleiros...

As relações das monjas com monges e clérigos deixaram vastos registros na literatura medieval. Essa convivência chegava a ser íntima, o que provocava consequências consideradas escandalosas. Além de homens, as monjas acolhiam também mulheres laicas e crianças nos conventos. Ao proibir esses contatos, tentava-se evitar a entrada do mundo externo no mosteiro. Tanto a regra de São Pacômio como a de São Bento pressupunham esse perigo, chegando a proibir que os monges trocassem experiências de suas vidas mundanas anteriores. ${ }^{5}$ Os ouvidos são o canal por onde pode entrar a corrupção da alma e do corpo e, nesse sentido, São Leandro aconselhava Santa Florentina, sua irmã:

Te ruego, hermana querida que no admitas en tu compañía a las mujeres que no tienen tu misma profesión; pues no podrían sugerirte más que las cosas que aman, es decir, las del mundo. Huye de los cantos de las sirenas y defiende tus oídos de las lenguas aduladoras. Protege tu corazón con el escudo de la fe y tu frente con el arma triunfadora de la cruz contra aquellas que no han profesado el mismo género de vida que tu (PÉREZ DE URBEL, 1934, p. 249).

Entretanto, as relações clandestinas das monjas também eram fonte de preocupação para o poder laico, como se pode ver nas Siete Partidas:

Gravemente yerran los omes que se trabajan de corromper las mugeres religiosas, porque ellas son apartadas de los vicios, e de los sabores deste mundo. E se encierran en el monasterio para fazer aspera vida, con intención de servir a Dios. ${ }^{6}$

Obviamente, era proibido acolher homens na clausura, mas era comum hospedar mulheres laicas. Isto provocou admoestações frequentes por parte dos superiores das ordens, por considerarem que, sob pretexto de receber mulheres piedosas, muitas vezes con- 
taminava-se o ambiente com falatórios e costumes pouco edificantes (ARANGUREN, 1974, p. 132). De qualquer forma, jamais se conseguiu que os cenóbios femininos deixassem de acolher mulheres laicas, embora se tentasse que as visitas e estadas necessitassem da autorização das hierarquias superiores e que a convivência intramuros fosse limitada, com o intuito de evitar a promiscuidade e a perturbação da rotina conventual. ${ }^{7}$ Talvez, os hóspedes eventuais não chegassem a perturbar demasiadamente o cotidiano dos mosteiros, mas aqueles que passavam grandes temporadas levavam consigo hábitos mundanos, além de séquitos de criados, o que afrontava a regra.

Com o objetivo de evitar situações extremas, determinou-se em que áreas do recinto monástico se poderia permitir a circulação ou permanência de laicos, onde poderiam comer e dormir. Proíbese a presença laica no dormitório comunitário, na sala do capítulo, na enfermaria e no claustro. Com relação aos horários de entrada ou de saída, jamais se poderia abrir a porta depois do poente e antes do nascer do sol (POWER, 1922, p. 401-403). Entretanto, pela frequência com que os relatórios de visitas, e as Codificações Cistercienses registram a recomendação de que os visitantes respeitassem determinados limites físicos dentro do mosteiro, e de que as mulheres laicas não pernoitassem com as religiosas nos dormitórios, conclui-se que os preceitos não eram cumpridos. ${ }^{8}$

Para Leão e Castela, sobretudo no caso dos mosteiros situados nas proximidades do Caminho de Santiago, há ainda que considerar o trânsito intenso de peregrinos. Muitos dos mosteiros femininos tinham hospedaria e, embora se prescreva que as monjas não devam atender diretamente os peregrinos, as reclamações dos superiores indicam a quebra da clausura.

Os mosteiros femininos, em especial aqueles mais ligados à monarquia e à alta nobreza, são amiúde palco de celebrações e cerimônias. Destaca-se o caso do Mosteiro de Las Huelgas de Burgos que, devido a seus vínculos especiais com a monarquia castelhano-leonesa, suspendia a clausura para as festas de coroação dos monarcas, batizados dos infantes e funerais da família real (RODRÍGUEZ, 1907, p. 109).

Mas o fato é que as preocupações dos legisladores centravam-se na clausura ativa. Para eles, as monjas tinham hábitos pou- 
co recomendáveis: saíam e entravam dos mosteiros com demasiada frequência e ficavam fora por longos períodos. Os motivos variavam desde visitar parentes, curar-se de alguma doença, a própria gerência dos domínios monásticos, até a administração de seus patrimônios e assuntos particulares.

Ao longo do século XIII, é possível rastrear muitos testemunhos sobre essa questão. O Capítulo Geral de Cister, por exemplo, quando dedica-se às monjas, é unicamente para estabelecer normas sobre a clausura. Em 1213, decide que as religiosas só podem sair do mosteiro com a autorização do abade imediato, passando por cima da própria autoridade da abadessa. Em 1220, estabelece que os mosteiros que se negarem a aceitar a clausura estrita não poderão ser incorporados à Ordem, condição que volta a se repetir em 1230. Em decreto de 1249, avisa: "[...] ser decente e honesto para que por meio dessas virtudes se possam cumprir os mandamentos de Deus e se conformem as ordens". Os estatutos da Ordem, promulgados em 1256-1257, têm uma cláusula em que se ordena que as monjas devem permanecer enclausuradas, só podendo sair dos mosteiros em circunstâncias muito específicas (apud BAKER, 1978, p. 239). Em 1298, o papa Bonifácio VIII também se ocupou do tema da clausura, através da famosa decretal, Periculoso, que foi imediatamente acolhida pelo Capítulo Geral de Cister. ${ }^{9}$ Esta é a decretal que obriga as monjas à clausura perpétua e que se transformará na base legisladora da clausura até o Concílio Vaticano II.

A reação das religiosas a essas leis poderia, à primeira vista, ser classificada como descaso, a julgar pela forma como continuam a viver seu cotidiano, em sociedade. Tal situação leva os legisladores eclesiásticos a insistir no tema. O Libellus Antiquarum Definitionum, de Cister, registra a diferença entre os mosteiros de "clausura antiga", que se negaram a aceitar a decretal Periculosum, e os de "clausura nova" que a aceitaram (VIDAL CELURA, 1986, p. 319). Portanto, admitia-se a argumentação do costume, como sede jurídica legítima frente à autoridade.

Por outro lado, há uma particularidade extremamente importante que não pode passar despercebida. Muitas vezes, eram os próprios legisladores, cujos textos rigorosos não davam margem a interpretações, os primeiros a conceder permissões excepcionais aos mosteiros femininos que faziam parte de suas relações pessoais. 
Nesse aspecto, os exemplos são numerosos, dentro e fora da Península Ibérica (POWER, 1922, p. 369). Tampouco deve-se perder de vista o fato de que as petições de novas incorporações femininas à Ordem não paravam de aumentar, pese a rigidez com que o Capítulo Geral tratava o tema da clausura, transformando-o em condição sine qua non para o reconhecimento oficial dessas fundações.

Embora percebam-se matizes diversos na evolução da clausura ocidental e na oriental, é fato que, desde os primeiros legisladores monásticos, desenha-se uma clara diferença entre a clausura masculina e a feminina. Enquanto aos mosteiros masculinos apenas se lhes proíbe a entrada de mulheres e se recomenda aos monges que limitem as saídas, às monjas se lhes proíbe a entrada de qualquer pessoa laica, seja homem ou mulher. Para vários autores, esse radicalismo explica-se pela necessidade de preservar e guardar a virgindade e a castidade das religiosas. Mas, ainda assim, será preciso não esquecer que a clausura deixará de ser um elemento protetor para transformar-se em um bem em si mesmo.

\section{A institucionalização dos mosteiros femininos cistercienses}

As mulheres tiveram muitas dificuldades para serem reconhecidas oficialmente pela Ordem de Cister. Os primeiros monges cistercienses negavam os insistentes pedidos que lhes faziam as diversas comunidades femininas que desejavam seguir a reforma de São Bernardo.

É possível acompanhar essa história de rechaço por meio dos documentos institucionais da Ordem, sobretudo por aqueles produzidos no âmbito do Capítulo Geral. Mas é interessante adiantar que não se encontram registros de abades que, de forma individualizada, desestimulassem esses pedidos. Muito pelo contrário.

Tal como mostram os incontáveis estudos realizados sobre mosteiros femininos cistercienses por toda a Europa, as monjas tornaram-se realidade, especialmente graças ao incentivo e a ajuda de abades cistercienses, de bispos e dos desejos da aristocracia católica de fundar mosteiros. O fato é que se as monjas não podiam 
se declarar cistercienses de pleno direito, reconhece-se que são "seguidoras das observâncias de Cister". ${ }^{10}$

Para a sociedade em geral, o fato de que o Capítulo Geral não reconheça as monjas oficialmente não causa maiores problemas. Inclusive, no âmbito eclesiástico, a questão parece entender-se como mero formalismo. Os mosteiros femininos, apesar dos empecilhos colocados pelo Capítulo Geral, nunca tiveram reparos em se denominar cistercienses. Este é o caso do Mosteiro de Santa Maria de Gradefes que, em 1181, identifica-se como "mosteiro de santa maria de gradefes da ordem cisterciense” (BURÓN CASTRO, 1998, doc. 148).

A maior parte dos mosteiros femininos cistercienses de Leão e Castela foi fundada em meados do século XII, quando o Capítulo Geral ainda negava o reconhecimento de um ramo feminino da Ordem. Mas, como já se disse, a discussão de se era cisterciense de pleno direito ou não parecia importar pouco àqueles que desejavam fundar um mosteiro, chegando mesmo a usar de ironia. Assim o demonstra a condessa Estefanía Ramírez, na carta fundacional de Santa Maria de Carrizo:

Se a Ordem de Cister não quiser que se construa uma abadia de monjas em Carrizo, fica no poder e providência da condessa dona Maria, minha filha, fazer ali uma abadia de qualquer outra ordem que queira servir a Deus. (CASADO, 1983, doc. 38).

Em princípio, poder-se-ia supor que o não reconhecimento jurídico e institucional das monjas implicasse sérios problemas para os mosteiros, como a impossibilidade de usufruir dos privilégios e das isenções de que desfrutava a Ordem Cisterciense. Tal aspecto permite entender a amplitude e variedade que nessa época alcançava a compreensão sobre as instituições, uma vez que, por exemplo, na resposta ao deão da Catedral de Lincoln (Inglaterra) sobre a matéria, o Abade de Citeaux é taxativo quanto à impossibilidade de que as monjas, que se diziam cistercienses naquela região, pudessem também aproveitar dos privilégios recebidos pelos monges da Ordem (SCHINE, 1985, p. 86). Entretanto, a sociedade laica, assim 
como abades e bispos, no seu trato particular com esses cenóbios, estendia-lhes os mesmos direitos (DRAKATOS, 1986, p. 19).

Apesar das reticências e resistências de Cister, a difusão dos mosteiros femininos converteu-se num fenômeno de grandes proporções e o Capítulo Geral não podia se esquivar dessa realidade. Nessa perspectiva, uma análise que assuma uma visão institucionalista poderá concluir que a convivência entre os dois ramos da Ordem é uma história de "avanços e recuos", que se refletiu em conjunturas políticas que ora pareciam próximas à tolerância ora de rechaço radical e absoluto.

O primeiro reconhecimento oficial da Ordem com relação à existência das monjas ocorreu em 1186, a pedidos do rei Alfonso VIII de Leão e Castela, que não se conformava que o Capítulo Geral se negasse a conceder ao Mosteiro de Las Huelgas de Burgos o selo de cisterciense. Depois de intensas negociações, as Huelgas serão reconhecidas como parte integrante da Ordem Cisterciense, deslanchando um processo mais amplo que afetará a todos os outros mosteiros femininos. Assim, a abadia de Tart, primeiro mosteiro feminino francês a declarar-se cisterciense, será reconhecido como Capítulo Geral dos cenóbios de monjas que lhe são afiliados. As Huelgas de Burgos transformam-se na cabeça política e Capítulo dos mosteiros de Leão e Castela (BOUTON, 1986, p. 47).

A partir do final do século XII, o reconhecimento é oficial e definitivo. Mas, ainda assim, a sensação é de que o Capítulo deu existência oficial às monjas, sem qualquer intenção de assumi-las com todas as consequências e obrigações. Tal situação é evidente na resposta que o Capítulo Geral envia ao rei de Castela sobre a resistência que apresentavam algumas abadessas para submeter-se à liderança recentemente assumida pelo mosteiro de Las Huelgas:

Escribimos al Señor Rey de Castilla para decirle que no podemos obligar a las abadesas a ir al Capitulo a que se refiere. Pero si ellas quisieren ir, como ya les hemos aconsejado, quedaremos contentos (BOUTON, 1986, p. 67).

Ora, é difícil imaginar que o Capítulo Geral desse a mesma resposta se um mosteiro masculino se recusasse a comparecer às suas 
reuniões. São muitos os exemplos de punições sofridas por abades resistentes e desobedientes ao chamado da autoridade (ROMANI, 1989, doc. 118). Mas, devido às insistências do monarca, em 1199, o Capítulo parece assumir seu papel jurisdicional sobre as monjas:

Además de esto mandamos a todas las Abadesas de estos reinos de Castilla y León, que todos los años el día de la fiesta de San Martín confesor, concurran a celebrar Capítulo a dicho monasterio de Santa María la Real de Burgos como a su matriz y cabeza según está mandado por nuestro Capítulo General. (RODRÍGUEZ LÓPEZ, 1907, p. 76).

De qualquer forma, a relação continuará difícil, como comprovam as diversas decisões do Capítulo Geral de Cister tomadas desde então. Por exemplo, proíbe-se aos abades benzer as abadessas, provavelmente com o intuito de reduzir ao mínimo os contatos entre monges e monjas. Ao mesmo tempo, as pressões políticas, principalmente do papado e da alta nobreza, exigiam que o Capítulo admitisse novas incorporações e, de fato, o ramo feminino não para de crescer.

As aparentes contradições dessa trajetória era fruto de poderosas razões. A primeira talvez deva ser atribuída à dificuldade que esses homens tinham para controlar as religiosas, o que os levou, num primeiro momento, a rechaçar qualquer relação ou laço jurídico que se traduzisse em responsabilidade sobre elas. A segunda, quando a situação jurídica era incontornável tentaram a todo custo que as monjas aceitassem a clausura, para evitar problemas e escândalos. $\mathrm{Na}$ realidade, sequer pretendem assumir responsabilidades quanto à tutoria espiritual e aos serviços sacerdotais (THOMPSON, 1978, p. 342).

No âmbito eclesiástico, as mulheres não podem organizar-se em comunidades sem o aval e a tutela do corpo masculino. Como apresentado anteriormente, os mosteiros de religiosas fundados no oriente por São Pacômio e São Basílio representam as origens do cenobitismo feminino e seu nascimento está claramente vinculado à tutela masculina. No ocidente, na experiência iniciada por Cesário de Arles, a figura do praepositus, uma espécie de administrador temporal dos assuntos das monjas, constitui evidência da tutela 
masculina (CONNOR, 1972, p. 234-235). Para a Península Ibérica, na época visigoda, a tutela dos monges sobre as religiosas estava amplamente difundida e acabou por ser reconhecida como legítima pelo II Concílio de Sevilha, em 619 (VIDAL CELURA, 1986, p. 234-235). A sujeição das mulheres aos homens na vida religiosa é, portanto, tão antiga quanto o monacato. A tradição mantém-se ao longo da Idade Média e a experiência cisterciense europeia parece seguir esse mesmo padrão. Por trás de cada mosteiro feminino encontra-se a tutela e/ou proteção de um abade ou de um bispo. A partir do século XIII, até mesmo aqueles mosteiros que se constituem em cabeças de congregações, como é o caso das Huelgas de Burgos e de Tart, devem prestar obediência ao órgão superior do ramo masculino, o Capítulo Geral de Cister.

Sobre a abadia de Tart, o Capítulo Geral, personificado no abade de Cister, arroga-se os seguintes direitos: a) plenos poderes para corrigir e ordenar tudo o que for necessário, seja com relação à cabeça ou aos membros; b) nomear a abadessa e depô-la, segundo as regras da Ordem; c) jurisdição com relação a assuntos administrativos e proteção sobre as abadias já fundadas por Tart, bem como sobre as futuras; d) o abade de Cister deverá presidir a reunião anual de todas as abadessas das filiais de Tart, que terá lugar no dia de São Miguel, 29 de setembro; e) somente o abade de Cister tem o poder de dispensar abadessas de comparecer a essa reunião (BOUTON, 1986, p. 48).

$\mathrm{Na}$ Codificação de 1257, insiste-se sobre a paternitate monialium:

Todo abade que possuir a paternidade de uma abadia o fará a justo título e com boa fé por dez anos, assim como sobre outras coisas, e se derrogará sobre essas questões por juizo e pacificação final do capitulo geral. Todo aquele que for visitador de outras abadias de monges ou de monjas deverá deixar claro no seu relatório de visita que tem autorização para isso (LUCET, 1977, p. 349). ${ }^{11}$

Entretanto, os aspectos apontados anteriormente foram extraídos de documentos institucionais e jurídicos. O cotidiano da tutela das monjas apresenta um panorama muito mais conflituoso e os preceitos dificilmente se cumprem. Num plano institucio- 
nal e formalista, para os monges cistercienses, aceitar e acolher as religiosas significava ter o direito de controlá-las, e isso somente se concretizaria por meio do exercício da tutela e do cumprimento da clausura. Entretanto, no plano da política, as normas são tensionadas com outros valores, dos quais fazem parte, por exemplo, as fidelidades intergrupos de interesses (redes), cujas dinâmicas passam necessariamente pela negociação das regras.

Apesar da elaboração cuidadosa de um conjunto de regras e normas que regulassem a sujeição, era evidente que as religiosas que desejavam incorporar-se à Ordem não tinham uma vida recolhida. Entravam e saíam do mosteiro com muita frequência, gerenciavam diretamente sua vida em comum e suas vidas particulares, cumpriam com obrigações sociais e legais. Elas só necessitavam da tutela espiritual, enquanto eles queriam impor-lhes a tutela material. Então, para que a tutela fosse efetiva, era fundamental observar a clausura estrita. Mas essas mulheres já estavam acostumadas a um determinado modo de vida e a resistência a mudanças dura mais de dois séculos. Somente no final da Idade Média, o ramo masculino conseguiu submeter as monjas. ${ }^{12}$

Nesta perspectiva, a tutela masculina sobre os mosteiros femininos sugere algumas dúvidas ao historiador. Ao analisar a trajetória de certos cenóbios peninsulares, descobre-se que a tal tutela nem sempre se exerce de forma clara e que frequentemente é até impossível comprovar sua existência. Da mesma forma, há fortes evidências que indicam que o controle masculino não era visto como algo natural pelas religiosas, de forma geral, e que tal exigência acabava por fazer parte das estratégias políticas dos grupos que controlavam os mosteiros, compostos por eclesiásticos e laicos.

No que tange a essa questão, os documentos não permitem comprovar o envolvimento dos bispos de Leão e Castela na tutela do monacato cisterciense feminino. Ao mesmo tempo, o fato de que o ramo feminino de Cister não fosse oficialmente reconhecido pelo Capítulo Geral acaba por produzir situações jurisdicionais variadas, o que teria dificultado esses mosteiros a alcançarem um perfil jurídico comum.

De acordo com Jean de la Croix Bouton, estudioso das cistercienses francesas, antes do reconhecimento oficial da Ordem, as 
monjas estavam confiadas à proteção do bispo local ou do abade do mosteiro mais próximo (BOUTON, s/data, p. 25). Entretanto, no caso de Leão e Castela, a situação é bem diferente. Somente em poucos casos é possível comprovar documentalmente a tutela masculina e é a autoridade da abadessa que se registra de forma clara.

Após a incorporação das monjas à Ordem, os direitos do ramo masculino sobre as religiosas fica bem estabelecido:

[...] la visita canonica con todos los poderes añejos a este cargo. Su papel consiste en visitar anualmente la abadía; debe ser consultado en los casos de admisión y partida de monjas; es responsable del estado general de la disciplina y de la administración de lo material (BOUTON, s/data, p. 26).

Esses são os direitos específicos da visita canônica sobre um mosteiro feminino. A capacidade de ingerência nos assuntos da comunidade é ampla e, se efetivada, com grandes consequências. Assim, se, em Leão e Castela, os abades e bispos exercessem plenamente tais direitos, seria quase impossível que sua intervenção não tivesse deixado rastro na documentação. Ainda dentro das especificidades da região, será necessário indagar sobre o que terá levado esses mosteiros que gozavam de aparente autonomia jurídica a se submeter à jurisdição das Huelgas de Burgos.

Do que se conhece atualmente em termos dos registros documentais, não é possível saber se o monarca exerceu algum tipo de pressão direta sobre essas casas monásticas, com o intuito de transformar a sua fundação régia em cabeça política dos mosteiros femininos cistercienses de Leão e Castela. De qualquer forma, entrar na jurisdição das Huelgas significava alcançar o reconhecimento oficial da Ordem, o que pode ter contribuído para o ato de boa vontade.

Entretanto, a tutela masculina aparece nas reuniões dos capítulos gerais femininos, tanto em Tart quanto nas Huelgas. Deste último, destaca-se a presença de abades da Ordem e de bispos:

Sea patente a todos que Nos las Abadesas de los reinos de Castilla y León, conviene a saber: Yo María, Abadesa del Monasterio de Perales; Yo María, Abadesa del Monasterio 
de Gradefes; Yo Toda, Abadesa del Monasterio de Cañas; y Yo María, Abadesa del Monasterio de Torquemada; y Yo Urraca, Abadesa del Monasterio de Fuencaliente; y Yo Mencia, Abadesa del Monasterio de San Andrés de Arroyo; y Yo María, Abadesa del Monasterio de Carrizo, nos juntamos y concurrimos en el Monasterio de Santa maría la Real, cerca de Burgos, como en espiritual madre, [...] á celebrar el anual Capítulo por mandado de D. Guido, Abad del Císter y del Capítulo General de la misma Orden, estando presentes las religiosas personas de los Obispos de Palencia, Burgos y Siguenza, y juntamente los Abades del hábito y Orden cisterciense, Guillermo, de Scala Dei; Raimundo de Sacramenia; Nuño, de Balbuena; Pedro, de Fitero; Sancho, de Bonabal; Juan, de Sandobal; y Fegrino, de Bugedo. (RODRÍGUEZ LÓPEZ, 1907, p. 66).

Ressalta-se a diferença numérica entre abades e bispos presentes, dez, e as abadessas, oito. Este desequilíbrio permitiria supor que as propostas das abadessas teriam bastantes dificuldades em ser aprovadas, caso os abades e bispos não estivessem de acordo. Mas tal raciocínio supõe que as abadessas agissem em bloco, supondo que partilhassem interesses comuns, na qualidade de abadessas de Cister, o que talvez não fosse o caso. Essas senhoras eram principalmente representantes de suas respectivas linhagens e certamente esse dado tem grande peso em seu comportamento nas instâncias da instituição.

Do ponto de vista da norma da Ordem, a tutela masculina sobre as religiosas pode gerar resistências, protestos e até mesmo situações de crise. Embora a autoridade do abade de Cister fosse suprema para os dois ramos, masculino e feminino, sabemos que, em 1260, a abadessa das Huelgas de Burgos não permitiu que o referido abade exercesse seu direito de visita ao mosteiro. Esta desobediência custou à abadessa a deposição e às monjas que a apoiavam a excomunhão (RODRÍGUEZ LÓPEZ, 1907, p. 146). As eleições abaciais poderiam também propiciar discórdias. Por exemplo, na Inglaterra, os abades e bispos frequentemente negavam-se a referendar a eleita pela comunidade e pressionavam para que se elegesse alguém mais ao sabor dos interesses que eles representavam. 
Os momentos de tensão eram comuns e as monjas revoltosas eram castigadas com a excomunhão (POWER, 1922, p. 51).

De qualquer forma, era impossível evitar totalmente a tutela do prelado. Já que os monges se recusavam a benzer as monjas e as abadessas, elas necessitavam dos bispos para esses sacramentos. Uma bula de Clemente III, de 1188, tenta proibir a intromissão dos bispos nas eleições abaciais femininas, bem como o descumprimento dos estatutos da Ordem cisterciense e de seus privilégios ${ }^{13}$.

Antes da incorporação das monjas à Ordem, muitos cenóbios femininos estavam sob a tutela espiritual e material de bispos. ${ }^{14}$ Depois do reconhecimento oficial, muitos desses cenóbios tiveram sérias dificuldades para fazer valer seus "privilégios cistercienses", já que os bispos não se mostravam dispostos a perder a sua jurisdição. Por outro lado, o comportamento errático do Capítulo Geral nessa matéria facilitava e incentivava tais atitudes. É significativo que, no final do século XIII, ainda se possam encontrar registros de contendas entre mosteiros cistercienses femininos e bispos. Mas esses exemplos são mais comuns na Inglaterra (DRAKATOS, 1986, p. 20).

A efetividade de qualquer tipo de tutela depende muito da qualidade das partes envolvidas, ou seja, da correlação conjuntural de forças. Embora as fórmulas de obediência e de submissão sejam reproduzidas e preservadas, elas não garantem a efetividade. Parece claro que se a abadessa das Huelgas decidiu não permitir a entrada do abade de Cister é porque se sentiu respaldada por sua alta condição de nobre e também porque não era estranho que uma mulher de sua condição atuasse daquela forma.

Ainda sobre este particular, é importante sublinhar que há duas realidades diferentes no que diz respeito ao controle dos homens sobre as mulheres. Trata-se das diferenças que certamente existiam entre os mosteiros que estavam sob a tutela de um abade ou de um bispo e aqueles que deviam prestar contas a outro mosteiro feminino, como era o caso das congregações de Tart e das Huelgas. $\mathrm{Na}$ Inglaterra, onde todos os mosteiros cistercienses femininos estavam sob a tutela de bispos, a grande quantidade de relatórios de visitas parece evidenciar um controle férreo (POWER, 1922). Entretanto, não se conhecem relatórios de visita elaborados por abadessas visitadoras. Claro que a ausência de registros pode 
evidenciar lacunas documentais, mas também pode sugerir que havia maior autonomia nas redes de mosteiros cujas cabeças políticas eram constituídas por casas mater femininas.

\section{Considerações finais}

Do que se disse até aqui, espera-se ter conseguido apontar a necessidade de que os estudos das normas e das instituições na Idade Média sejam levados a cabo numa perspectiva social e política. No que se refere à incorporação das monjas à Ordem Cisterciense, bem como ao cumprimento de um dos princípios fundamentais da regra, a clausura, será preciso entender esse processo em sociedade e, sobretudo, sem perder de vista o que cada fundação monástica representava para a aristocracia cristã que se lhe vinculava.

As tensões e os conflitos registrados nos documentos que envolvem questões ligadas ao cumprimento da clausura, ao reconhecimento jurídico dos mosteiros ou aos vínculos jurisdicionais, deveriam ser explicados no contexto político de cada reino e de cada região, sem esquecer, por exemplo, as redes políticas e sociais em que estavam envolvidos aqueles atores. Bispos, abades, abadessas, nobres patronos, certamente recorriam aos discursos institucionais que tinham à disposição, quer para se fortalecer, quer para enfraquecer o inimigo. Para isso, lançar mão de estratégias como acusações de desrespeito à clausura das casas monásticas vinculadas aos oponentes, solicitar a excomunhão de alguma abadessa da linhagem inimiga, ou associar-se ao mosteiro régio das Huelgas de Burgos, para se livrar da tutela de um bispo que é membro de uma linhagem concorrente, talvez fossem estratégias que faziam parte do jogo político e que se somavam a tantas outras à disposição no cenário do poder.

Entretanto, também não pode passar despercebida a importância que adquire o cumprimento das regras e normas, bem como o reconhecimento institucional dos mosteiros, como parte do aparato que dá identidade à aristocracia cristã. Afinal, esses homens e mulheres da igreja são membros ativos de suas linhagens e a atuação e ocupação de espaços no âmbito eclesiástico é necessário para uma maior efetividade política. 
Nessa perspectiva, a vida monástica que os documentos registram, talvez, não devesse ser interpretada como evidência das dificuldades que aquelas mulheres tinham para cumprir regras virtuosas, ou do descaso/desprezo que a instituição masculina mostrava com relação às monjas, ou até mesmo da debilidade institucional da Ordem de Cister que, por meio do comportamento errático de seus abades, ia cedendo e abrindo exceções. Se as instituições e as normas monásticas forem entendidas dentro da cultura política da Baixa Idade Média, em seus aspectos corporativos, pactistas e personalistas, talvez a trajetória dos atores pareça menos desconcertante. Esta é uma hipótese de pesquisa que convida a revisitar os arquivos monásticos, que serviram de base a inúmeros trabalhos acadêmicos, para repensar as abordagens formalistas/institucionalistas e/ou as adeptas do modelo dos "domínios monásticos". ${ }^{15}$

Para retornar ao objetivo que se anunciava no começo deste artigo, o de tentar compreender o processo de institucionalização do monacato cisterciense feminino castelhano-leonês: parece evidente que os esforços de fundar um cenóbio respondem a um conceito de instituição bem assentado, pelo qual se reconhece uma noção de ordem, como afirmação de um modelo. Assim, a clausura constitui um ponto de ordem cuja vigência histórica é essencial para confirmar a própria ordem. Tal confirmação é o que institui (constrói) a instituição que, nesse caso, é mais do que uma função: é uma prova de ordem simbólica. O que torna um mosteiro feminino uma instituição aos olhos de seus contemporâneos passa necessariamente pela referência da clausura, embora o reconhecimento (aderência) do factício à realidade esteja sujeito às circunstâncias da política. Isto, entretanto, não significa que a instituição corra o risco de se transformar em ficção aos olhos daqueles que a vivem.

\section{INSTITUTIONS, NORMS AND MONASTICISM IN LION AND CASTILE (XIIITH CENTURY)}

Abstract: This article intends to explain the monastic enclosure in a political culture perspective that embodied the cistercian rules, mainly the feminine branch, in Lion and Castile in the XIIIth century. As part of the problem will be necessary to analyze how the nuns were institutionalized, in the masculine perspective of the Cistercian order. The tensions and conflicts registered on the 
documents that involved the observance to enclosure, the juridical recognition of the monasteries, or the jurisdictional bounds, must be explained in the political context of each kingdom or region, without forgetting the political and social nets where those actors belonged.

Keywords: Medieval Monasticism. Enclosure. Cistercian Order. Cister in León and Castile.

\section{Notas}

${ }^{1}$ De acordo com Santo Agostinho: “[...] que vosso monastério seja uma fortaleza. Que não tenha mais que uma porta com chave para que nenhum laico queira entrar, nem sequer um monge; a menos que seja um ancião, testado, preocupado con sua alma e capaz de examinar com cuidado vossas ações". (Apud PARISSE, M. Les nonnes au Moyen Age. Clamecy, 1983, p. 181).

${ }^{2}$ No Concílio de Orleáns (549), já se faz a distinção entre os mosteiros femininos, que seguem a regra cesariana, e os demais.

${ }^{3}$ Seria importante estudar com detalhe os motivos que levaram cada um desses eclesiásticos a optar por regras mais ou menos rígidas, coisa que ainda não foi respondida pela historiografia.

${ }^{4}$ É interessante recordar que a decisão do Concílio de Coyanza coincide com a fundação por Cluny do primeiro monastério feminino adscrito à Ordem: a abadia de Marcigny. Do ponto de vista político, e haja vista a grande difusão de Cluny na Península Ibérica, nos séculos XI e XII, essa poderia ser uma boa hipótese de pesquisa. Afinal, as fundações femininas cluniacenses estão fortemente vinculadas à nobreza local...

${ }^{5} \mathrm{Na}$ Regra pacomiana: "Los monjes no pueden publicar en el monasterio lo que han hecho u oído fuera. Los que van de camino, navegan o trabajan fuera, no pueden hablar en el monasterio de lo que han visto hacer fuera". Na Regra beneditina: "Ningún hermano puede contar a otro lo que ha visto u oído fuera del monasterio". Na Regra tarnatense: "No se atrevan a referir lo que han visto hacer fuera, si no es que edifica a los oyentes." (Apud VIDAL CELURA, 1986, p. 121). ${ }^{6}$ Partida VII, Título XIX, Ley I. In: Las sietes partidas del rey don Alfonso el Sabio. Madrid: Real Academia de la Historia, 1809.

${ }^{7}$ Desde 1222, na Inglaterra, foi decidido no Concílio de Oxford, que as monjas só podíam receber hóspedes com a autorização de seus respectivos bispos. (POWER, 1922, p. 415).

${ }^{8} \mathrm{Na}$ Distinctio XV, de 1237: "Para que ninguém entre no claustro das monjas - Ninguém, além dos visitadores, será admitido no claustro das monjas, a não ser que seja pessoa tão 
honesta e tão reverenciável que não se the possa negar a entrada sem causar grave escândalo e dano. $O$ abade visitador de fato deve estimar o numero de pessoas e àquelas que vierem a transgredir esse limite, seja abadessa ou priora, avisa-se que serão depostas. Na Distinctio XV, de 1257: "Sobre a não entrada no claustro das monjas" [...] Por outro lado, as mulheres laicas não devem pernoitar no claustro nem nas enfermarias. (Apud LUCET, 1977, p. 351). ${ }^{9}$ Destaca-se o começo desta decretal: "Desiring to provide for the perilous and detestable state of certain nuns, who, having slackened the reins of decency and having shamelessly cast aside the modesty of their order and of their sex, sometimes gad about outside their monasteries in the dwellings of secular persons, and frequently admit suspected persons within the sames monasteries, to grave offence of Him to Whom they have, of their own will, vowed their innocence, to the opprobium of religion and to the scandal of very many persons..." (Apud POWER, 1922, p. 344).

${ }^{10}$ Isto confirma-se, por exemplo, na Bula que o papa Alexandre III dirige aos monastérios cistercienses femininos do Yorkshire: "Bulla Alexandri Papae tertii de Confirmatione. Alexander episcopus, servus servorum Dei... Dei et beati Benedicti regulam et institutionem Cistercien". (Apud DRAKATOS, 1986, p. 19).

${ }^{11}$ No original: Quicumque abbas pater paternitatem alicuis abbatie monialium iusto titulo, bona fide, et nomine sue abbatie decennio possiderit, illam de cetero possideat et habeat, mostique super hoc questionibus ordinis indicio terminatis et sopitis, omnibus de cetero super hoc capituli generalis audientia derogetur. Et quicumque visitaverit aliquam monachorum vel monialium abbatiam, in carta sue visitationis cuius auctoritate visitat scribere non omittat.

${ }^{12}$ Embora o tema da imposição da clausura no final da Idade Média ultrapasse a cronologia que delimita este artigo, é importante destacá-lo como outra possibilidade de pesquisa. Entretanto, talvez o melhor caminho para pensar o assunto não seja simplesmente o da vitória da autoridade, que finalmente se impõe aos particularismos, mas o da recriação do percurso que a aristocracia cristã vai estabelecendo como estratégia e lógica de afirmação e de identidade de ordem superior. 13 “"...] que ningún Obispo impida la regular elección de vuestra Abadesa, y de ninguna manera se entrometa contra los Estatutos de la Orden cisterciense y la autoridad de vuestros privilegios..." (RODRÍGUEZ LÓPEZ, 1922, p. 42).

${ }^{14} \mathrm{Na}$ Inglaterra à exceção dos monastérios de Marham e de Tarrant, os demais estavam sob a tutela de bispos. (DRAKATOS, 1986, p. 19-20).

${ }^{15}$ Trata-se do modelo que se iniciou com a proposta de José Angel García de Cortázar. El domínio del monasterio de San Millán de la Cogolla (s. X a XIII). Salamanca: Univ. de Salamanca, 1969. Esta proposta foi seguida por praticamente todos os estudos que se realizaram sobre mosteiros ibéricos nos trinta anos seguintes. 
Instituições, normas e monacato em Leão e Castela (séc. XIII)

\section{Referências}

ALONSO ÁLVAREZ, Raquel. Los promotores de la Órden del Císter en los reinos de Castilla y León: famílias aristocráticas y damas nobles. Anuario de Estudios Medievales (AEM) n. 37, v. 2, jul./dic. p. 653-710, 2007.

ARANGUREN, Ignacio; San Elredo de Rieval. La Vida de la Reclusa. Cistercium, n. 133, 1974, p. 128.

BOUTON, Jean-de-la Croix. Les Moniales Cisterciennes. 02 vols, Grignan, p. 42, 1986.

. L'Abbaye de Tart et ses filiales aux Moyen-Age. Mélanges Anselme Dimier, tomo II, vol. 3, s/data, p. 25.

BURÓN CASTRO, Taurino. Colección Documental del Monasterio de Gradefes (10541299). Tomo I, León: S. Isidoro, 1998.

CASADO, María Concepción. Colección Diplomática del Monasterio de Carrizo, 2 tomos, León: San Isidoro, 1983.

COELHO, Maria Filomena. Expresiones del poder feudal. El Císter femenino en León (siglos XII y XIII). León: Univ. de León, 2006.

. A territorialização de mosteiros nobres: experiências de assentamento e de domínio (Leão, séc. XII-XIII). Territórios e fronteiras, v. 5, n. 1, p. 34-56, 2011. CONNOR, Michael. Le Gouvernement des Moniales. Point de vue historique. Collectanea Cisterciensia, n. 34, 1972.

DRAKATOS, Dimitri. The English Cistercian Nunneries of Yorkshire between 1267 and 1340. Kent State University, 1986.

GARCÍA DE CORTAZAR, José Angel; TEJA CASUSO, Ramón. Monasterios cistercienses em la España Medieval.Palencia: Fund. Sta María La Real, 2008.

LECLERCQ, Jean. La femme et les femmes dans l'oeuvre de Saint Bernard. Paris, 1982.

LÓPEZ DE GUEREÑO SANZ, María Teresa. Santa María de Huerta, panteón de la nobleza castellana. De Arte, Universidad Autónoma de Madrid, n. 6, p. 37-56, 2007.

LUCET, Bernard. Les codifications cisterciennes de 1237 et de 1257. Paris, 1977.

PÉREZ DE URBEL, Justo. Los monjes españoles en la Edad Media. Madrid, 1934.

POWER, Eileen. Medieval English Nunneries. Cambridge: 1922.

Anos 90, Porto Alegre, v. 20, n. 38, p. 127-149, dez. 2013 


\section{Maria Filomena Coelho}

RODRÍGUEZ LÓPEZ, Amancio. El Real monasterio de Las Huelgas de Burgos y el Hospital del Rey. Burgos, 1907.

ROMANI MARTINEZ, Miguel. Colección diplomática del Monasterio Cisterciense de Santa María de Oseira. Santiago de Compostela, 1989.

SCHINE, Penny. The Lady and the Virgin: Immage, Attitude and Experience in Twelfth-Century France. Londres, 1985.

SMITH, Julie Ann. Ordering Women's Lives: Penitentials and Nunnery Rules in the Early Medieval West. Aldershot: Ashgate, 2001.

THOMPSON, Sally. The problem of the cistercian nuns in the twelfth and early thirteenth centuries. In: BAKER, Derek. Medieval Women, Oxford, 1978.

VIDAL CELURA, Ramón. Evolución Histórica de la Institución de la Clausura en el Monacato Femenino. Cistercium, n. 170/ 171, p. 113-124/ p. 297-338, 1986.

VOGUÉ, Adalbert. Cesareo de Arlés y los orígenes de la clausura de las monjas. XX Semana de Estudios Monasticos. Abadía de Silos, 1986.

Recebido em: 30 de junho de 2013. Aprovado em: 15 de setembro de 2013. 